\title{
Active Carbon as Nanoporous Material for Solving Environmental Problems
}

\author{
V.M. Mukhin ${ }^{1 *}$, A.Ye. Burakov², I.V. Burakova ${ }^{2}$ \\ ${ }^{1}$ OAO "Elektrostal Research and Production Association "Neorganika", \\ 4, K. Marx St., Elektrostal, Moscow region, 144001, Russia \\ ${ }^{2}$ Department of Technology and Equipment for Nanoproduction, Tambov State Technical University, \\ 1, Leningradskaya St., Tambov, 392000, Russia \\ * Corresponding author. Tel.: +7 (919) 65197 57. E-mail: victormukhin@yandex.ru
}

\begin{abstract}
This review article presents the authors' view of the role and place of active (activated) carbon (AC) in solving various environmental problems ranging from protecting the environment from harmful industrial emissions to endoecology - the internal ecological purity of a man. The nanoporous structure of active carbon is represented by micropores $(<1.2 \mathrm{~nm})$, supermicropores $(1.2-3.2 \mathrm{~nm})$, and mesopores $(3.2-200 \mathrm{~nm})$. The developed nanoporous structure provides AC with a developed internal surface reaching $1500-2500 \mathrm{~m}^{2} / \mathrm{g}$. The volume of nanopores absorbs any toxins from air, water and soil, providing protection of the atmosphere, hydrosphere, and lithosphere. With increasing anthropogenic and technogenic load on the biosphere, the role of AC in solving environmental problems will be constantly increasing.
\end{abstract}

\section{Keywords}

Active carbon; ecology; biosphere protection; detoxification of soils; purification of drinking water; purification of gases.

(C) V.M. Mukhin, A.Ye. Burakov, I.V. Burakova, 2017

\section{Introduction}

Active carbon is the oldest natural adsorbent discovered by a man. Data on its use as a medicine is available in Egyptian papyri dated about $1550 \mathrm{BC}$, and for water purification in India - $400 \mathrm{BC}$.

The First World War (1914-1918) gave impetus to a large-scale production of active carbon in all industrialized countries (including Russia) for its use in gas masks.

Currently, AC-based adsorption technology is widely used throughout the world, which is largely due to three factors: first, they ensure the production of high purity products in a number of industries; secondly, they promote the introduction of highintensity technologies; thirdly, which is especially important, they allow creating new products and new areas of their application. They solve a wide range of problems in gas production and processing, new power engineering (supercapacitors), gold mining and processing of non-ferrous metal ores, medicine and public health, drinking water supply and wastewater treatment, space defense and exploration, in short, in all spheres of the world economy.

An increase in the population and intensive industrial development have put forward new tasks, in particular, due to the pollution of biosphere by anthropogenic emissions, which have become especially relevant by the middle of the twentieth century. In practical solution of these problems active carbon plays an important role.

Progressive pollution of the biosphere has made environmental security an important component of national security in general. Today, almost the entire planet and, especially, the areas of mass residence of people are exposed to serious environmental threats, the main of which are: radiation contamination of the territories; oppression of soils by acid rains; soil contamination with chemicals and pesticides; oil spills on land and at sea and the destruction of the atmosphere. One of the ways to solve this important 
task is to develop and use universal materials, such as carbon adsorbents - active carbon [1].

The problems of global pollution of the environment were raised even earlier by the Russian scientist, professor of Dmitry Mendeleev University of Chemical Technology of Russia, N.V. Keltsev, who proposed the mainstream to resolve the situation. He wrote: "At the present time, when a matter of life and death is no longer confined to the army, but to all humanity concerned with the catastrophic pollution of the biosphere, it is time to appeal to adsorption - one of the most effective methods of protecting the environment from pollution" [2].

Due to their physical and chemical properties, carbon adsorbents (active coals) are unique and ideal sorption materials that allow solving a wide range of issues of ensuring chemical and biological safety of humans, environment and infrastructure.

Active carbons are highly porous solids obtained on the basis of carbonaceous raw materials (coal, wood, peat, etc.) with a developed internal surface reaching $2500 \mathrm{~m}^{2} / \mathrm{g}$ and high absorption characteristics for impurities to be cleaned in air, water, soil, etc. In the porous structure of active carbon (in the volume of micropores and mesopores), all types of organic microimpurities are absorbed by adsorption forces (surface interaction forces) [3]. The characteristic of the porous structure of active carbon is given in Table 1.

It should be noted that new environmental threats, for the prevention of which $\mathrm{AC}$ is necessary, are constantly emerging.

Table 1

\section{Porous structure of active carbon}

\begin{tabular}{|c|c|c|c|}
\hline Type of pores & $\begin{array}{c}\text { Pore } \\
\text { volume, } \\
\mathrm{cm}^{3} / \mathrm{g}\end{array}$ & Pore size, nm & $\mathrm{S}_{\mathrm{sp}}, \mathrm{m}^{2} / \mathrm{g}$ \\
\hline Macropores & $0.2-0.6$ & $\begin{array}{l}\text { Pore radius } \\
>100-200\end{array}$ & $0.5-2.0$ \\
\hline $\begin{array}{l}\text { Mesopores } \\
\text { (transitional } \\
\text { pores) }\end{array}$ & $0.1-0.4$ & $\begin{array}{c}\text { Pore radius } \\
1.5-1.6-100-200\end{array}$ & $50-400$ \\
\hline $\begin{array}{l}\text { Micropores: } \\
\text { micropores } \\
\text { proper }\end{array}$ & $0.3-0.7$ & $\begin{array}{l}\text { Slot half width size } \\
\quad<0.6-0.7\end{array}$ & $1200-1500$ \\
\hline Supermicropores & $0.1-0.3$ & $\begin{array}{l}\text { Slot half width size } \\
0.6-0.7-1.5-1.6\end{array}$ & $500-800$ \\
\hline $\begin{array}{l}\text { Total pore } \\
\text { volume }\end{array}$ & $0.7-2.0$ & & $1800-2000$ \\
\hline
\end{tabular}

Table 2

Ecological technologies based on active carbon use

\begin{tabular}{|c|c|}
\hline $\begin{array}{l}\text { Biosphere } \\
\text { Component }\end{array}$ & Carbon Absorption Technology \\
\hline Atmosphere & $\begin{array}{l}\text { Solvent recuperation } \\
\text { Sanitary cleaning of waste gases, } \\
\text { including desulphurization } \\
\text { APP gas cleaning system } \\
\text { Capture of gasoline vapors released by } \\
\text { motor vehicles } \\
\text { Destruction of chemical weapons } \\
\text { Destruction of solid household waste } \\
\text { Cleaning the air in residential and working } \\
\text { premises (air conditioning) }\end{array}$ \\
\hline Hydrosphere & $\begin{array}{l}\text { Purification of drinking water } \\
\text { Disinfection of sewage } \\
\text { Treatment of liquid radioactive waste } \\
\text { Extraction of gold and non-ferrous metals }\end{array}$ \\
\hline Lithosphere & $\begin{array}{l}\text { Protection of soils from xenobiotics, } \\
\text { including pesticides } \\
\text { Remediation of soils } \\
\text { Zones of sanitary protection of water } \\
\text { sources }\end{array}$ \\
\hline Human being & $\begin{array}{l}\text { Means of individual and collective } \\
\text { protection of filter type } \\
\text { Production of chemical drugs, vitamins, } \\
\text { antibiotics } \\
\text { Entero- and hemosorption } \\
\text { Production of organic food }\end{array}$ \\
\hline
\end{tabular}

Let us dwell in more detail on the most important ecological technologies based on the use of active carbon (Table 2).

\section{The Main Ecological Applications of Active Coals}

\section{Agriculture}

A particularly significant threat to the biosphere is the reduction of soil fertility and even the complete depletion of farmland as a result of technogenic activity. But the soil on the planet is only $6 \%$ of the total land area, with almost $30 \%$ of the most fertile soils - chernozem - belonging to Russia and Moldova. Considering that at the end of the 21 st century more than 10 billion people will live on the planet, the protection and rehabilitation of soils must be given the highest priority.

When solving ecological problems of the agroindustrial complex, active carbon has such advantages as the selectivity of sorption of organic toxicants, the universality of sorption properties, high absorptive capacity, hydrophobicity, convenient formulation (grains, powder) and low cost.

The idea of coal-sorption detoxification consists in the introduction of $\mathrm{AC}$ into contaminated soil 
Table 3

Efficiency of fertility restoration of soils polluted with residues of herbicides, with the help of active coal "Agrosorb" at the rate of application of $100 \mathrm{~kg} / \mathrm{ha}$

\begin{tabular}{lcc}
\hline $\begin{array}{c}\text { Herbicide residues } \\
\text { in Soil }\end{array}$ & Crop & $\begin{array}{c}\text { Indicators of saved } \\
\text { yield of test cultures, } \\
\text { \% to contaminated } \\
\text { control }\end{array}$ \\
\hline Chlorsulforone, 0.2 g/ha & $\begin{array}{c}\text { Cucumber } \\
\text { Beet } \\
\text { Radish }\end{array}$ & $\begin{array}{c}16-20 \\
58-63\end{array}$ \\
& Cucumber & $23-28$ \\
Terbacil, $1.4 \mathrm{~kg} / \mathrm{ha}$ & Beet & $64-69$ \\
& Radish & $30-39$ \\
Pikloram, $2 \mathrm{~g} / \mathrm{ha}$ & Cucumber & $22-24$ \\
Simazin, 50 g/ha & Tomato & $22-26$ \\
& Tomato & $98-100$ \\
Chlorsulforone, 0.4 g/ha & Beet & $98-99$ \\
& Radish & $98-100$ \\
\hline
\end{tabular}

in the form of grains or powder with a volume of micropores of $0.20-0.30 \mathrm{~cm}^{3} / \mathrm{g}$ and subsequent fixing it to a depth of $10-15 \mathrm{~cm}$; then, the crop is sown in the coal-treated soil.

The results of experiments (see Table 3 ) performed in the laboratory of artificial climate (ACL) with different types and concentrations (corresponding to real residual amounts) of herbicides in soils, indicate that active carbon is indeed a universal means for restoring the fertility of contaminated soils, regardless of the type and residual content of the herbicide, increasing yield by $20-100 \%$ [4].

Another important result of coal-sorption detoxification of soils is the production of ecologically pure plant and vegetable products. Table 4 presents the results of comparative experimental studies on crops which were cultivated using conventional technology and a carbon adsorbent. As can be seen, the introduction of active coals to contaminated sites in an amount of up to $100 \mathrm{~kg} / \mathrm{ha}$ (in the case of a barley grain crop up to $200 \mathrm{~kg} / \mathrm{ha}$ ) allows sharply reducing, and in some cases, completely eliminating the accumulation of herbicides in plant and vegetable products. Thus, the use of $\mathrm{AC}$ directly affects the nutrition and quality of life of a man.

According to the data of All-Russian Research Institute of Phytopathology RAS, the expected ecological and economic effect of soil detoxification reaches 500 US dollars per ha and only in the Moscow region (Russia) can amount to 30 million US dollars per year.

\section{Purification of drinking water and wastewater}

Despite huge reserves of fresh water on our planet, the shortage of drinking water on Earth is constantly growing. Currently, out of 6 billion people of the earth's population, 1.5 billion (i.e. one quarter) lack drinking water (there is data that by 2025 this number will reach 2.5 billion people). This is especially true in the countries of North Africa and South-East Asia, as well as in China and India. It is expected that in 202076 million people will die due to dirty drinking water.

To provide cities and large settlements with drinking water, surface water sources must be cleaned, and we can't do it without active carbon.

In order to remove the bulk of pollutants from natural and waste water, a wide range of techniques are used, including flotation, coagulation, oxidation, sedimentation, filtration and final sorption with granulated active carbon.

One of the methods of purification of drinking water is its treatment with powdered activated carbon (PAC) (see Fig. 1). Usually, a suspension of 3-7 wt. \% PAC in water is preliminarily prepared, and then dosed into the stream of water to be treated. In recent years for these purposes, as a rule, active carbon from wood of the OU type has been used. However, the requirement to increase the efficiency of sorption process necessitated the improvement of qualitative PAC parameters of the UAP type on the basis of coal raw material, which increased the absorptive capacity for highly toxic compounds (chlorophenols and pesticides) [5].

An increase in the depth of water purification is achieved by supplementing the traditional technology of water treatment with the stages of water ozonation and its subsequent processing with granulated active carbon. Ozone-sorption treatment is provided by

Table 4

Accumulation of herbicides by agricultural crops

\begin{tabular}{lccc}
\hline $\begin{array}{c}\text { Herbicide } \\
\text { dose, kg/ha }\end{array}$ & $\begin{array}{c}\text { Active coal } \\
\text { dose, kg/ha }\end{array}$ & Test-culture & $\begin{array}{c}\text { Herbicide } \\
\text { content in the } \\
\text { yield, mkg/kg }\end{array}$ \\
\hline Treflan -1 & - & Tomatoes & 28 \\
Treflan -1 & 100 & Tomatoes & 0.6 \\
Treflan -1 & - & Carrot & 95 \\
Treflan -1 & 100 & Carrot & not found \\
2.4-D -5 & - & Barley & 220 \\
2.4-D -5 & 200 & Barley & not found \\
2.4-D -10 & - & Barley & 670 \\
2.4-10 & 200 & Barley & not found \\
2,4-Dichlorophenoxyacetic acid & \\
\hline
\end{tabular}




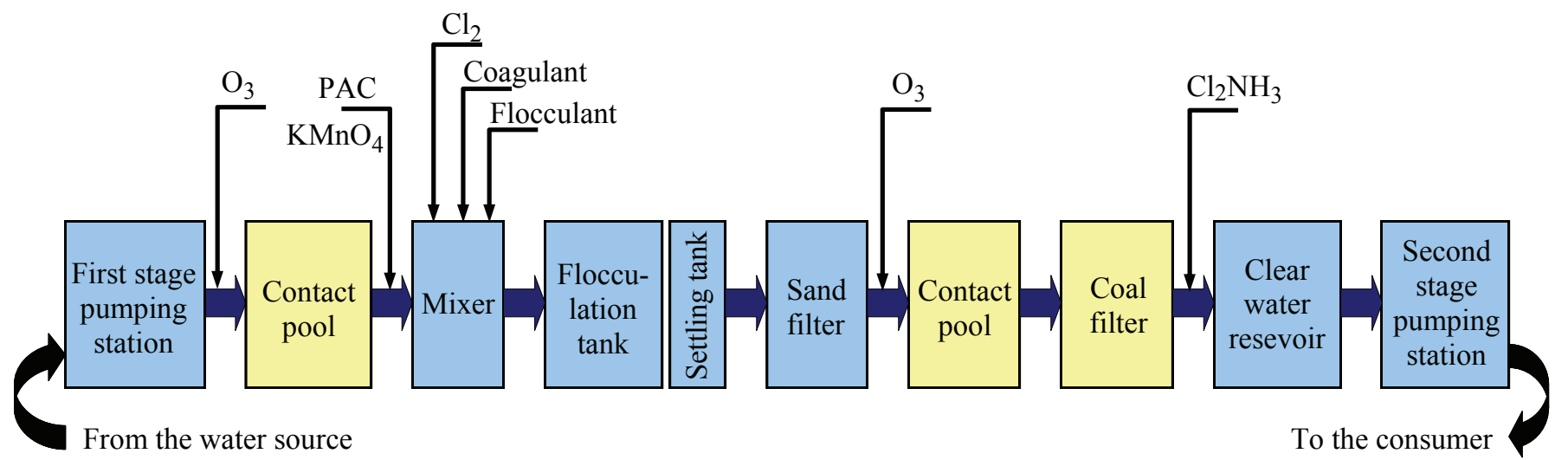

Fig. 1. Scheme of carbon-adsorption treatment of water:

$\square$ - existing processes; $\square$-perspective processes

the design of treatment facilities of new water supply stations. The classical scheme of carbon-adsorption treatment of water is shown in Fig. 1.

In 2002, for the first time in Russia, in connection with putting into operation a modern block of ozonesorption purification of water with a capacity of $240,000 \mathrm{~m}^{3}$ per day at Rublevsky Waterworks, the task of developing a new type of granular active carbon (GAC) was set. Thus, on the basis of coal raw materials from Kuzbass: hard coal charge of SS grade and semi-coke of long-flame coal, the active coal under the trademark HYDROSORB was developed.

The properties of the new active carbon HYDROSORB and the operating regulations ensure its effective use in the preparation of drinking water, which is confirmed by water quality control data after the 4th unit and traditional RVS facilities: according to generalized indicators of organic pollution (organic carbon content, permanganate oxidability) water purification efficiency exceeds that in traditional technology by $40-50 \%$; when there are unpleasant smells in the Moscow River water, its reliable deodorization is ensured; by-products of ozonation (formaldehyde, in particular) are absent in water after carbon filters [6].

HYDROSORB coal was sent to the Center of Aquatic Technologies (Karlsruher, Germany) to assess the possibility of its use at the waterworks in Germany, which take water from open water sources. The evaluation of the adsorption activity of coal shown in Table 5 indicates that the iodine number of the HYDROSORB coal is slightly lower than ROW $08 \mathrm{~S}$ reference coal, butit is at a sufficiently high level in comparison with the requirements of DIN-EN 12915. Besides, having the adsorption capacity for organic pollutants reflected by the difference in the values of DOC before and after water treatment with coal and being an indicator of the depth of their extraction from water, active carbon HYDROSORB significantly exceeds the standard, demonstrating the advantage which is most important for water preparation. In addition, the commissioning of the plant was conditioned by the absence of halogenated hydrocarbons in HYDROSORB-purified water.

In general, the tests, conducted in Germany at the waterstation Hosterwitz (Dresden), show that active coal HYDROSORB meets the requirements of the European standard and can be recommended for use in the process of drinking water preparation in Western Europe.

It is known that low-quality drinking water is the main way of getting xenobiotics into the human body. Therefore in all countries of the world much attention is paid to household filters for post-treatment of drinking water, equipped with active coal. It is the coal that absorbs the bulk of organochlorine toxicants formed when chloramines are introduced into the water supply network to prevent the contamination of the tubes with bacteria.

Table 5

Adsorption properties of active carbon for water purification

\begin{tabular}{|c|c|c|c|c|}
\hline \multirow{2}{*}{ Active carbon } & \multirow{2}{*}{$\begin{array}{c}\text { Iodine } \\
\text { number, } \\
\text { mg/g }\end{array}$} & \multirow{2}{*}{$\begin{array}{c}\text { Adsorption } \\
\text { capacity } \\
\text { for DOC at } \\
C=1.0 \mathrm{mg} / \mathrm{g}\end{array}$} & \multicolumn{2}{|c|}{$\begin{array}{l}\text { Concentration in water after filter, } \\
\qquad \mathrm{mkg} / \mathrm{l}\end{array}$} \\
\hline & & & $\begin{array}{l}\text { 1,2-cis- } \\
\text { dichloroethene }\end{array}$ & $\begin{array}{l}\text { 1,2-cis- } \\
\text { dichloroethene }\end{array}$ \\
\hline Hydrosorb & 850 & 24.0 & $<0.1$ & $<0.1$ \\
\hline $\begin{array}{l}\text { ROW } 08 \mathrm{~S} \\
\text { (standard) }\end{array}$ & 1000 & 12.0 & $<0.1$ & $<0.1$ \\
\hline DIN-EN 12915 & $>600$ & - & $<0.1$ & $<0.1$ \\
\hline
\end{tabular}


Sewage is, perhaps, the most obvious and visible damage to the environment, primarily the hydrosphere (rivers, lakes, seas and even oceans). It is believed that about $1 / 3$ of the world's fresh water supply is needed to provide MPC (maximum permissible concentrations) of pollutants in discharged wastewater to dilute it. Therefore, in our country in the early 1980s we began to pay special attention to this aspect of the protection of the biosphere.

Wastewater treatment is usually multi-stage in nature and includes operations of sedimentation, filtration, coagulation, flotation, chemical and, finally, sorption treatment using active coal, ion exchange resins, zeolites and other absorbers.

Adsorption processes in wastewater treatment can be divided into regenerative ones, when the ultimate goal is to capture and return valuable components into the economic circulation, and destructive ones, in which the absorbed toxic substances are to be destroyed (thermal decomposition) during regeneration of the adsorbent. Adsorption with activated coal is used to remove highly toxic organic pollutants and hardly oxidizable substances from wastewater. It is realized in those cases when biochemical treatment of effluents is either impossible or does not give the necessary effect, which is often characteristic of closed water-rotation systems of industrial enterprises.

Biochemical purification is based on the ability of various microorganism communities to use organic substances in wastewater as a source of carbon for their nutrition. These microorganisms contact the water to be purified in the form of active silt or biofilm. In nature, there are two types of bacteria: aerobic - living in the presence of oxygen - and anaerobic - able to exist without access to oxygen. It should be noted that the replacement of biochemical treatment with physico-chemical treatment of effluent using activated carbon sorption reduces the area of treatment facilities 3-6 times, with simultaneous increase in purification efficiency (the degree of extraction of pollutants) from $80-90$ to $90-95 \%$.

Typically, the most effective sorption cleaning of effluents is that with low-concentration of target components, when the required quality of the purified water is achieved by using a minimum amount of sorbent. The economic efficiency of sorption purification of wastewater is confirmed, in particular, by the results of a comparative assessment by American experts of the possibility of obtaining $500,000 \mathrm{~m}^{3}$ of clean water per day in the region of Southern California using a seawater desalination plant with a nuclear reactor and through deep sorption purification of available sewage. It turned out that in the first case the cost of water is 1.8 times higher, and construction costs are 7.5 times higher.
In view of the foregoing, the development of circulating water cycles and closed water supply and sewerage systems, based on the purification and neutralization of sewage with the use of sorption, should be considered the most preferable and promising for oil refining and petrochemical enterprises.

For the processes of sorption purification of sewage, both granular and powder active carbons can be used. In Russia, granular active carbons of AG-3, BAU-A, KAD-iodine grades and powder grades OU-A, OU-B, UAF, UAM, KAD-ground are used for such processes.

\section{Automotive industry}

Recently, the pollution of the environment by motor transport has attracted much attention. In addition to the inflow of hydrocarbons with the exhaust gases from internal combustion engines, a significant amount of them enter the atmosphere as a result of fuel evaporation from engine power systems (fuel tanks, carburetors and other devices).

The use of adsorbers for catching petrol vapors in cars VAZ 2110-2115, equipped with AC, prevented them from releasing vapours into the atmosphere in the amount of 10,000 tons, which undoubtedly contributed to the improvement of the ecological situation in the cities of the Russian Federation [7].

It is noteworthy that in the world of motor vehicles the electric cars are becoming more widely used - cars with electric motors. The source of electricity in them is an accumulator based on ionizers (supercapacitors) - an electrolyte system with a lowash $(<0.5$ mass. \%) PAC having a developed mesoporous structure $\left(0.3-0.4 \mathrm{~cm}^{3} / \mathrm{g}\right)$, capable of producing a developed surface to form an electrolyte film, which allows increasing the accumulation of electricity hundreds of times. The era of electric cars will certainly improve the ecological situation of cities significantly.

\section{Sanitary cleaning of gases, including radioactive ones}

A special area of application of active carbon in gas purification, which is usually related with negative economic costs, is the sanitary cleaning of gases (usually in the form of various ventilation flows). This area of carbon adsorption technology involves the processes of desulfurization of gases (removal of $\mathrm{SO}_{2}, \mathrm{SO}_{3}, \mathrm{H}_{2} \mathrm{~S}$ and other sulfur compounds), adsorption of harmful and foul-smelling substances, including low-concentration organic vapours, and the removal of radioactive gases generated by nuclear power plants [4]. 
Comparative testing of sorbents

\begin{tabular}{|c|c|c|c|c|}
\hline The name of the indicator & $\begin{array}{l}\text { Standard according } \\
\text { to Specification } \\
\text { (fraction } \\
1.7-3.4 \mathrm{~mm} \text { ) }\end{array}$ & $\begin{array}{c}\text { NORIT brand } \\
\text { RKJ-1 } \\
\text { (fraction } \\
1.0-2.0 \mathrm{~mm} \text { ) }\end{array}$ & $\begin{array}{c}\text { VSK-5IK } \\
\text { (fraction } \\
1.0-2.0 \mathrm{~mm} \text { ) }\end{array}$ & $\begin{array}{c}\text { VSK-5IK } \\
\text { (fraction } \\
1.7-3.4 \mathrm{~mm})\end{array}$ \\
\hline Dynamic activity for stable molecular iodine, $\mathrm{g} / \mathrm{dm}^{3}$ & More than 35 & 38 & 153 & 53 \\
\hline $\begin{array}{l}\text { The permeability factor for iodine radionuclide } \\
\text { vapors-131, \% }\end{array}$ & Less than 0,0050 & 0,003 & 0,0009 & 0,0013 \\
\hline Cleaning efficiency, $\%$ & 99,9950 & 99,9970 & 99,9991 & 99,9987 \\
\hline $\begin{array}{l}\text { Resistance of a layer of sorbent with a height } \\
\text { of } 5.0 \mathrm{~cm} \text { at } V_{\mathrm{sp}}=0.5 \mathrm{l} /\left(\mathrm{min} \cdot \mathrm{cm}^{2}\right), \mathrm{mm} \text { w.c. }\end{array}$ & 4,5 & 11,6 & 11,5 & 4,2 \\
\hline
\end{tabular}

Since the radiation contamination of the territory is one of the main threats to the biosphere, it is necessary to develop sorbents to extract radionuclides from air emissions and liquid radioactive waste $(\mathbf{L R W})$. So, on the basis of active carbon, we developed a new sorbent VSK-5IK from coconut shell. The results of its tests on the extraction of iodine radionuclides from gas purification systems of nuclear power plants are given in Table 6 .

As can be seen from Table 6, the comparative tests of RKJ-1 sorbents produced by "Norit" and VSC5IK produced by OAO Elektrostal RPA "Neorganika" in the correlated graining (smaller than that in the specification) show that dynamic activity for stable molecular iodine of the Russian sorbent is 4.0 times greater, and the purification efficiency for iodine-131 radionuclide vapours is an order of magnitude higher. And even in larger graining $(1.7-3.4 \mathrm{~mm})$, it exceeds RKJ-1.

\section{Detoxification of a human body}

At the present stage of the development of the society, different aspects of human health can not be considered without taking into account the ecological state of the environment. Polluted environment, deterioration of the quality of food and drinking water are certainly harmful to health, therefore neutralization of the negative impact of these factors on a human being is necessary. Of course, the main strategy in this area is to solve the problems of deep cleaning or elimination of industrial emissions into the atmosphere, hydrosphere and lithosphere. It is known, however, that it is very expensive, since the costs of purifying emissions and recycling waste are in many cases comparable to those needed for setting the main production. Another effective way to ensure effective neutralization of the negative impact of a number of environmental factors on humans is the development of drugs and detoxification methods that ensure the creation of conditions for an intrinsic ecological purity inherent in a healthy individual - endoecology.

Thus, Table 7 shows the efficiency of AC SCHS (Spherical Carbon Hemosorbent) similar to FAS to reduce the specific activity (in $\mathrm{Bq} / \mathrm{kg}$ ) of ${ }^{134} \mathrm{Cs}$ in organs and tissues of animals after adsorption detoxification by hemosorption.

However, there is also a more accessible and simple method of detoxifying the body through oral intake of active coal - enterosorption. The most outstanding Russian enterosorbent FAS-3 was developed at OAO Elektrostal RPA "Neorganika" by V.V. Guryanov. It is made by liquid forming of furfural copolymers and some resins (epoxy, coal, etc.), added in an amount of 3-7 mass. \%, followed by thermal curing. Carbonization and activation are carried out on rotating electric furnaces with a retort diameter of $325 \mathrm{~mm}$.

Table 7

Total specific activity (in $\mathrm{Bq} / \mathrm{kg}$ ) of ${ }^{134} \mathrm{Cs}$ in organs and tissues of animals before and after adsorption detoxification by SUGS

\begin{tabular}{lccc}
\hline \multicolumn{1}{c}{ Organs, tissues } & $\begin{array}{c}\text { Before } \\
\text { the procedure }\end{array}$ & $\begin{array}{c}\text { After } \\
\text { hemosorption }\end{array}$ & $\begin{array}{c}\text { After } \\
\text { enterosorption }\end{array}$ \\
\hline Liver & $145 \pm 21$ & $66 \pm 10$ & $66 \pm 10$ \\
Langs & $131 \pm 25$ & $110 \pm 21$ & - \\
$\begin{array}{l}\text { Gastrointestinal } \\
\text { tract }\end{array}$ & $170 \pm 20$ & $56,5 \pm 2,5$ & $71 \pm 8$ \\
Muscles & $580 \pm 120$ & $207 \pm 43$ & $276 \pm 57$ \\
Bones & $225 \pm 22$ & $70 \pm 7$ & $107 \pm 10$ \\
Blood & $69 \pm 17$ & $24 \pm 5$ & $35 \pm 9$ \\
\hline
\end{tabular}

* During 10 days 
The efficiency of FAS-3 enterosorbent in treatment of diseases

Name of the clinic

Research Institute of Transplantology and Artificial Organs

Children's Regional Clinical Hospital of Nizhny Novgorod Region

Research Institute of Physical and Chemical Medicine No. 3

Central Research Institute of Epidemiology

General detoxification of the body as a form of prophylaxis
Strong clinical effect

In patients with rheumatoid arthritis, systemic lupus erythematosus, bronchial asthma, there was a positive clinical dynamics of the pathology process, manifested in the disappearance of pain in the joints and a decrease in body temperature

In patients aged 1 to 16 years with the following pathology - food and drug allergies, acute and chronic renal failure, neurodermatitis, psoriasis, diabetes mellitus, bronchial asthma, acute poisoning with plant poisons - the general condition improved, symptoms of intoxication disappeared. In case of skin diseases, itch passed and the cutaneous pattern was restored

In patients with acute allergic reactions, bronchial asthma, chronic diseases of the digestive system, there was a significant reduction in pathology

It had a detoxification and antidiarrheal effect in patients with foodborne toxins, including salmonella etiology

It promotes elimination of ecotoxicants contained in the environment and food products
Table 8 below shows the results of FAS sorbent tests in various clinics in Russia at doses of $0.3 \mathrm{~cm}^{3} / \mathrm{kg}$ of a body weight per day.

Thus, speaking at the All-Russian Symposium on Adsorption Technologies (1994), Russian Academician $\mathrm{Yu}$. M. Lopukhin informed the audience that one-third of the US population takes active coal as an enterosorbent daily.

Taking into account that practically all the manufacturers of chemical-pharmaceuticals, vitamins, antibiotics and other drugs use active carbons for their refining or isolation of target components, the role of active carbons in directly providing human health is indispensable.

\section{Conclusion}

From the above it follows that active carbon plays the leading role in protecting all spheres of the biosphere: the atmosphere, the hydrosphere, the lithosphere, and the man himself as the main object of the biosphere.

The total volume of AC production in the world is 1 million 250 thousand tons per year and it is characterized by a steady growth of $5 \%$ annually. Speaking about the level of ecology and economy of the country, it is necessary to pay attention to the specific production of AC which in the US, Japan, and Western Europe is at the level of $0.5 \mathrm{~kg}$ per person per year. Hence, for the sustainable development of the economy and high quality of life of the world population, the production of active carbon in the world should approximate 3 million tons per year.

Constantly developing scientific, technical, economic and other aspects of the ecology, along with a progressively increasing number of implemented environment measures, indicate a clear shift in the emphasis of the world community to the issues of environmental protection from anthropogenic pollution. This allows us to state that the twenty-first century marks a new era for mankind, an era of protection of the biosphere, where the leading role will be played by active coal - carbon adsorbents in technology for cleaning diverse industrial emissions and protecting human beings from anthropogenic impacts.

\section{Acknowledgments}

The work was financially supported by the Ministry of Education and Science in the framework of the project of State Assignment GK No. 16.1384.2017.

\section{References}

1. Mukhin V.M. Aktivnyie ugli kak vazhnyiy faktor razvitiya ekonomiki i resheniya ekologicheskih problem [Active coals as an important factor in the development of the economy and solution of environmental problems]. Himiya $v$ interesah ustoychivogo razvitiya [Chemistry for Sustainable Development], 2016, No. 24, pp. 309-316 (Rus)

2. Keltsev N.V. Osnovyi adsorbtsionnoy tehniki [Basics of adsorption technique]. M.: Chemistry, 1976, 511 p. (Rus)

3. Mukhin V.M., Kurilkin A.A., Voropaeva N.L., et al. Mesto aktivnyih ugley $\mathrm{v}$ ekologii i ekonomike, novyie tehnologii ih proizvodstva [The place of active coals in ecology and economics, new technologies for their production]. Sorbtsionnyie i hromatograficheskie protsessyi [Sorption and chromatographic processes], vol. 16, issue 3, pp. 346-353 (Rus)

4. Mukhin V.M., Spiridonov U.Y., Lupashku T.G. Detoxification of pesticides-polluted soil by adsorption on activated carbons. Chemistry Journal of Moldova, 2009, vol. 4, No. 1, pp. 72-74.

5 Mukhin V.M., Klushin V.M. Proizvodstvo $i$ primenenie uglerodnyih adsorbentov [Production and application of carbon adsorbents]. M.: Minobrnauki RF, D.I. Mendeleev RHTU, 2012, 307 p. (Rus)

6. Volkov V.Z., Koverga A.V., Blagova O.E., et al. Novyie metodyi podgotovki pitevoy vodyi na Rublevskoy vodoprovodnoy stantsii [New methods for preparing drinking water at the Rublyovskaya waterworks]. Vodosnabzhenie i sanitarnaya tehnika [Water supply and sanitary engineering], 2003, No. 5 (Part 2), P. 9-14 (Rus)

7. Mukhin V.M., Tarasov A.V., Klushin V.N. Aktivnyie ugli Rossii [Active coals of Russia]. M.: Metallurgiya, 2000, 352 p. (Rus) 